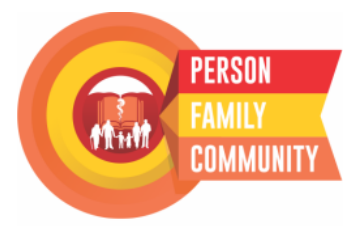

Journal Homepage:

https://jurnal.ugm.ac.id/rpcpe
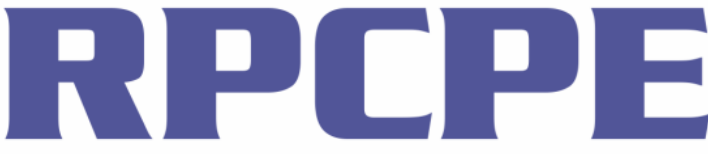

ISSN 2613-943X (print)

ISSN 2620-5572 (online)

Review of Primary Care Practice and Education (Kajian Praktik dan Pendidikan Layanan Primer)

\title{
The Need of Trusted Primary Care: Lessons Learnt from the COVID 19 Outbreak in Indonesia
}

\author{
Trevino Aristarkus Pakasi ${ }^{1,2}$ \\ ${ }^{1}$ Division of Family Medicine Department of Community Medicine; School of Medicine; Universitas Indonesia; Indonesia \\ ${ }^{2}$ Klinik Satelit Universitas Indonesia Makara; Indonesia \\ Corresponding Author: \\ Trevino Aristarkus Pakasi: Department of Community Medicine, Faculty of Medicine Universitas Indonesia, Jl. Pegangsaan Timur \\ no. 16 Jakarta Pusat - 10320, Indonesia \\ E-mail: pakasitrevino@gmail.com \\ To cite this article: \\ Pakasi TA. The need of trusted primary care: lesson learnt from the COVID 19 outbreak in Indonesia. Rev Prim Care Prac and Educ. \\ $2020 ; 3(2): 3-5$.
}

\section{INTRODUCTION}

Indonesia declared COVID 19 as an outbreak since March 2020, when the President of Indonesia announced the first two cases who were already cured. Since then many publications as well as information has been distributed through social media. The hoax buster of the government had already caught and put 134 hoaxes on their website within only the first month ${ }^{1}$. Thus, one can imagine how difficult it is for Indonesian people to fully understand the situation of the outbreak and to properly respond to it.

Worldwide, COVID-19 cases have increased exponentially and it was estimated that Indonesia would reach 20,000 patients at the end of March 20202. Fortunately, the facts show that up till the 6th of April 2020, Indonesia had reported 2,491 cases $^{3}$, which is much lower than the estimation.

What happened to the estimation? Was it wrong or are there under-reported cases that occurred in the community? Or was it because of the effectiveness of the government interventions?

\section{OVERVIEW OF THE COVID 19 OUTBREAK IN INDONESIA AND OTHER COUNTRIES}

Considering the examples in South Korea, Iran and Italy, there were four phases of the COVID 19 outbreak $^{2}$ :

1. Delayed incidence;

2. Exponential increase of the incidence;

3. Plateau of the incidence; and

4. Gradual decrease of the cases.

The delayed incidence after the first case that was found in those countries represented the history of the disease. Every infectious agent, including the SARS-CoV2, needs incubation time before it can be identified in the clinic. It is worthy to note that this virus may be spread from 'a healthy' person without any symptoms. It is easy for us to avoid standing or sitting near a person who has a cough or runny nose, or sneezing. However, it is difficult to differentiate the virus carrier without any symptoms and to make a safe distance afterwards.

Because many people may be infected and spread the virus without knowing their status, a few weeks later there will be an exponential increasing of new cases. But as seen in the experience in China, as well as in Italy and Iran, the governments were successful in slowing down the increase and there came the third phase, slowing down of the new cases or plateau. And finally, the number of cases will gradually decrease since many of the patients get well, and recover from the disease.

How is the situation in Indonesia? If we look at the day to day reporting from the Indonesian government, Indonesia is experiencing the exponential phase and is expecting thousands of new cases. However, as mentioned above, after two months the number of cases reached only around 2,000 cumulatively. Yet, this is still unmanageable, which is evident by the greater number of fatality cases compared to the number of available hospital beds in Jakarta, surrounding Jakarta and in Java Island, where most Indonesians live.

One possibility for the low case number was because the number of laboratories to confirm the diagnosis are few and the capacity of all laboratories to find new cases is extremely low compared to the number of people.

The possibility exists that actually there were a large number of undetected cases all over Indonesia, based only on the case findings from the laboratory analysis, because the Ministry of Health made a decision at first to only use 12 laboratories all over Indonesia to confirm COVID-194. 
Later, another decision was made to establish 169 more testing sites which was followed by another 132 referral hospitals ${ }^{5}$. Again, the numbers continued to be low to the number of expected cases and the testing capacity was complicated by the geographical constraints to reach a more significant portion of the population.
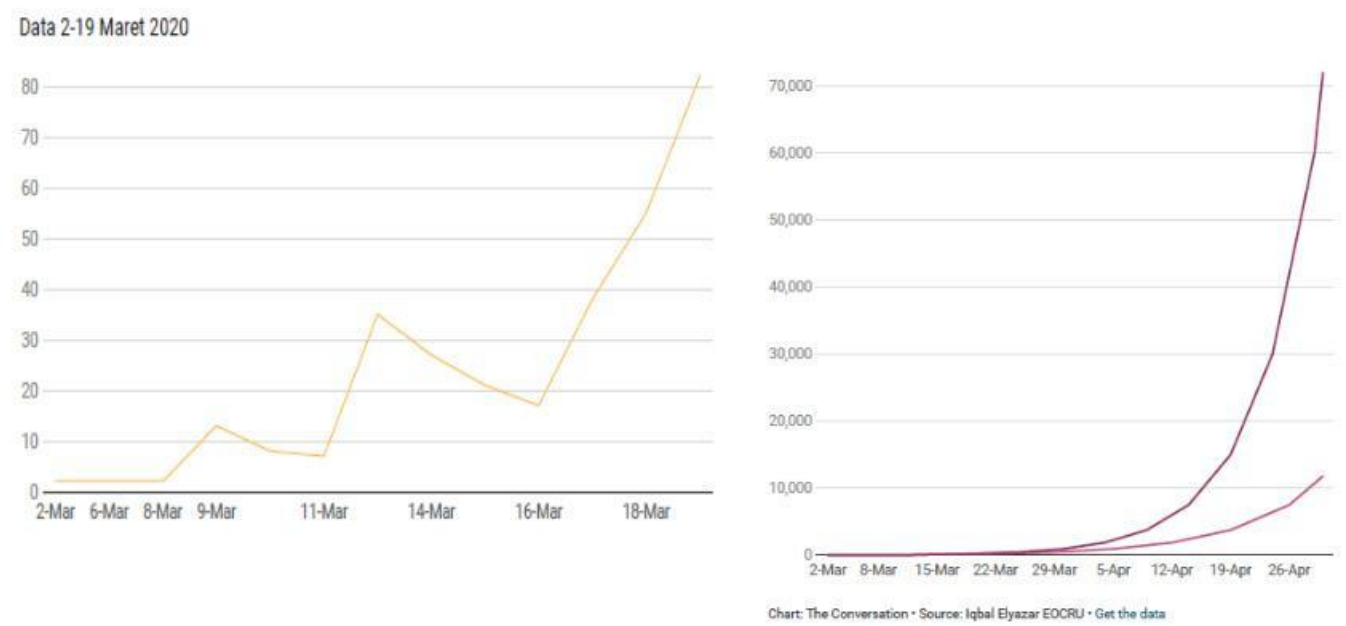

Figure 1. The increasing number of COVID19 incidence in Indonesia (left) compared with the prediction (right). (Source: The Conversation, March 20 2020)

\section{TASK OF PRIMARY CARE DURING THE OUTBREAK COMPARED TO THE NORMAL DAILY SITUATION}

Looking back to the task of primary care, in 2019 after the implementation of the national social insurance, it was planned that almost all citizens of Indonesia would have their own family doctor or primary care facility. The main task of these family physicians in the primary care facilities was to fill the gap between the primary and secondary care services, creating a screening between the patients in a healthy condition and those with debilitating disease, as well as provide a more convenient setting for follow up after any disease occurrence (i.e., rehabilitation or death) ${ }^{6,7}$.

When we consider the task of primary care in the outbreak situation as in the case of COVID-19, we should actually rely on primary care to delay the expansion of new cases and find them at the earliest phase, treat them well and prevent the spread of the disease, or to refer the cases as soon as possible to prevent fatality. This expectation fits the pathogenesis of COVID-19, for which as primary care doctors, we could analyse patients and categorize them based on their risks and clinical status to properly manage the patient's treatment ${ }^{8,9}$.

However, this was not the case during the outbreak in Indonesia. The focus of the government was to provide curative care by ramping up laboratory test sites and referral hospitals, instead of strengthening the primary care services $^{10}$.

In the general guideline, the role of the primary care provider is more focused on the surveillance and health promotion, followed by treating patients at the earliest phase as possible $e^{10,11}$. But actually, because the capacity of the primary care services including all government's facilities and private clinics is much greater than the task being explicitly given in

the guideline, we need to reformulate the extent of our contributions. For example, primary care doctors can focus on the task to screen patients using remote consultation. To accomplish this task, primary care physicians may use online consultations, in the form of video call or chatting depending on the situation and the needs of the patients. This telemedicine approach is even more effective if the doctors make health promotional contact to their captive markets, i.e., Puskesmas and its coverage population, private clinics and all clients covered in their capitation through the $\mathrm{BPJS}^{12,13}$, as currently done during the COVID-19 outbreak by the government through short message services (SMS).

\section{CONCLUSIONS}

Indonesia is still expecting high incidence of COVID-19 in this exponential phase of the pandemic. However, due to the limitations of the laboratories compared to the number of the population and the geographical constraints, we need to reformulate the role of primary care providers to contribute in the screening and treating of patients accordingly at the earliest possible clinical stage, by properly assessing and managing the risk and referring patients appropriately whenever necessary because the number of hospitals are still very limited. The use of econsultation or remote consultation should be considered to screen more patients based on their reported complaints and history to minimize the physical contact but still continue assisting the patients based on their needs.

\section{REFERENCES}

1. Hoaks buster. https://www.covid19.go.id/hoaks-buster/. Accessed: 6 March 2020

2. Elyazae I, Nasir S, Sumowidagdo. Penularan COVID-19 di Indonesia bisa tembus 11-71 ribu akhir April jika tak ada intervensi cepat. March 
20, 2020. Available at: https://theconversation.com/penularan-covid- 19di-indonesia-bisa-tembus-11- 71-ribu-akhir-april-jika-tak-ada-intervensicepat-129619. Accessed: 6 March 2020

3. Peta sebaran. https://www.covid19.go.id/situasi-virus-corona/. Accessed: 6 March 2020.

4. Decree of the Minister of Health of the Republic of Indonesia Number HK.01.07 / MENKES / 182/2020 Regarding the 2019 Coronavirus Disease Examination Laboratory Network (COVID-19).

5. Decree of the Minister of Health of the Republic of Indonesia Number HK.01.07 / MENKES / 169/2020 Regarding the Designation of Referral Hospitals for Prevention of Certain Emerging Infection.

6. Indonesian Medical Council Regulation Number 65 Year 2019 Concerning Professional Education Standards for Family Medicine Specialist Family Services Doctors.

7. Azwar A. Introduction to Family Physician Services. Jakarta, The Indonesian Doctors Association Publishing Foundation; 1997

8. Rifki N. Holistic Diagnosis. 3rd ed. Jakarta, Department of IKK FKUI; 2017

9. Susilo A, Rumende Cm, Pitoyo CW et.al. Coronavirus Disease 2019: Current Literature Review. J INA Disease, 7 (1), 2020: 45-67

10. Isbaniah F, Kusumowardhani D, Sitompul PA, et.al. Guidelines for the Prevention and Control of Coronavirus Disease (COVID 9) 4th Revision. Jakarta: Directorate General of Disease Prevention and Control of the Ministry of Health Republic of Indonesia, 2020.

11. IRO FK UGM. Peran dokter layanan primer, menyehatkan penduduk Indonesia. April 4, 2017. Available at: http://fk.ugm.ac.id/perandokter-layanan-primer-menyehatkan-penduduk-indonesia/ Accessed 7 th April 2020.

12. Mold F, Hendy J, Yi LL, de Lusignan S. Electronic consultation in primary care between proiders and patients: systematicrReview. JMIR Med Inform 2019; 7 (4): e13042.

13. Greenhalg T, Koh GCH, Car J. Covid-19: a remote assessment in primary care. BMJ 2020: 368: m1182. 